\title{
Engineering Approaches in Plant Molecular Farming for Global Health
}

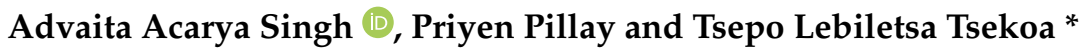

check for updates

Citation: Singh, A.A.; Pillay, P.;

Tsekoa, T.L. Engineering Approaches in Plant Molecular Farming for Global Health. Vaccines 2021, 9, 1270. https://doi.org/10.3390/ vaccines 9111270

Academic Editors: Kathleen Hefferon and Srividhya Venkataraman

Received: 1 September 2021

Accepted: 14 October 2021

Published: 3 November 2021

Publisher's Note: MDPI stays neutral with regard to jurisdictional claims in published maps and institutional affiliations.

Copyright: (c) 2021 by the authors. Licensee MDPI, Basel, Switzerland. This article is an open access article distributed under the terms and conditions of the Creative Commons Attribution (CC BY) license (https:/ / creativecommons.org/licenses/by/ $4.0 /)$.
Future Production, Chemicals Cluster, Council for Scientific and Industrial Research, Pretoria 0001, South Africa; ASingh4@csir.co.za (A.A.S.); PPillay3@csir.co.za (P.P.)

* Correspondence: TTsekoa@csir.co.za; Tel.: +27-(0)12-841-3274

\begin{abstract}
Since the demonstration of the first plant-produced proteins of medical interest, there has been significant growth and interest in the field of plant molecular farming, with plants now being considered a viable production platform for vaccines. Despite this interest and development by a few biopharmaceutical companies, plant molecular farming is yet to be embraced by 'big pharma'. The plant system offers a faster alternative, which is a potentially more cost-effective and scalable platform for the mass production of highly complex protein vaccines, owing to the high degree of similarity between the plant and mammalian secretory pathway. Here, we identify and address bottlenecks in the use of plants for vaccine manufacturing and discuss engineering approaches that demonstrate both the utility and versatility of the plant production system as a viable biomanufacturing platform for global health. Strategies for improving the yields and quality of plant-produced vaccines, as well as the incorporation of authentic posttranslational modifications that are essential to the functionality of these highly complex protein vaccines, will also be discussed. Case-by-case examples are considered for improving the production of functional protein-based vaccines. The combination of all these strategies provides a basis for the use of cutting-edge genome editing technology to create a general plant chassis with reduced host cell proteins, which is optimised for high-level protein production of vaccines with the correct posttranslational modifications.
\end{abstract}

Keywords: plant-made pharmaceutical; molecular farming; vaccine; glycoengineering; tyrosine sulfation; proteases inactivation

\section{Introduction}

Vaccination has been the most effective intervention in reducing death and morbidity resulting from infectious diseases in the last century. Vaccines stimulate humoral and cellular immunity in humans, thereby providing protection against infectious disease [1]. Several vaccines are protein-based; however, extracting these proteins from their natural sources may pose risks and may not be scalable. Inexpensive and scalable methods of production of recombinant protein are highly desirable. Traditional recombinant protein production approaches used are microbial fermentation, mammalian and insect cell culture, and transgenic animals. These systems have their drawbacks concerning upfront capital costs, scalability, and recombinant protein safety and authenticity [2-4].

Plant molecular farming (PMF) refers to the use of plants for the production of recombinant proteins that are of pharmaceutical or industrial interest. The first plant-produced protein of pharmaceutical interest was human growth hormone, produced in transgenic tobacco in 1986 [5]. The plant-based production of the first antibody was demonstrated in tobacco in 1989 [6]. The plant system offers a faster alternative and potentially more cost-effective and scalable platform for the mass production of proteins of pharmaceutical interest. The system also has a low risk of contamination compared with insect and mammalian cell culture production systems [7-9]. The high degree of similarity between the plant and mammalian secretory pathways makes it possible to efficiently produce highly 
complex protein-based vaccines [10]. Plant-based production has thus gained significant interest and is gaining wider acceptance [11,12].

Numerous plant species repurposed as recombinant protein production platforms include tobacco, potato, tomato, alfalfa, safflower, carrot, lettuce, strawberry, moss, duckweed, maize, wheat, and rice. Consolidation of the "molecular farming community" around the use of tobacco (Nicotiana tabacum) and its close relative Nicotiana benthamiana (N. benthamiana) as the most widely used species for protein expression has been seen recently [13]. These plant systems may be utilised as whole plants or in organ cultures (such as hairy roots) and cell suspension cultures. Various expression strategies have been exploited, such as (i) transgenic or transplastomic lines that are highly scalable; (ii) the use of transient expression in non-transgenic plants for rapid manufacturing; (iii) constitutive vs. tissue-specific vs. inducible expression; and (iv) different protein-targeting strategies to control product accumulation or post-translational modification for the facilitation of downstream processing [14-16]. Plants have proven versatile in producing a range of proteins, including proteins for nutritional supplements, industrial enzymes, and proteins of pharmaceutical interest $[17,18]$. Some examples of the many pharmaceutical proteins of interest are protein subunits, virus-like particles, monoclonal antibodies, cytokines, and human serum albumin. Despite the advantages of plant-production systems, some challenges may prevent the system from competing with the more conventional proteinbased vaccine production systems, such as the folding of highly complex proteins and the processing of unique posttranslational modifications. The ability to tailor the plant system through cellular engineering techniques or process modification (Figure 1) to address these challenges is discussed in this review, demonstrating the versatility of the system and its ability to meet the demands of vaccine producers.

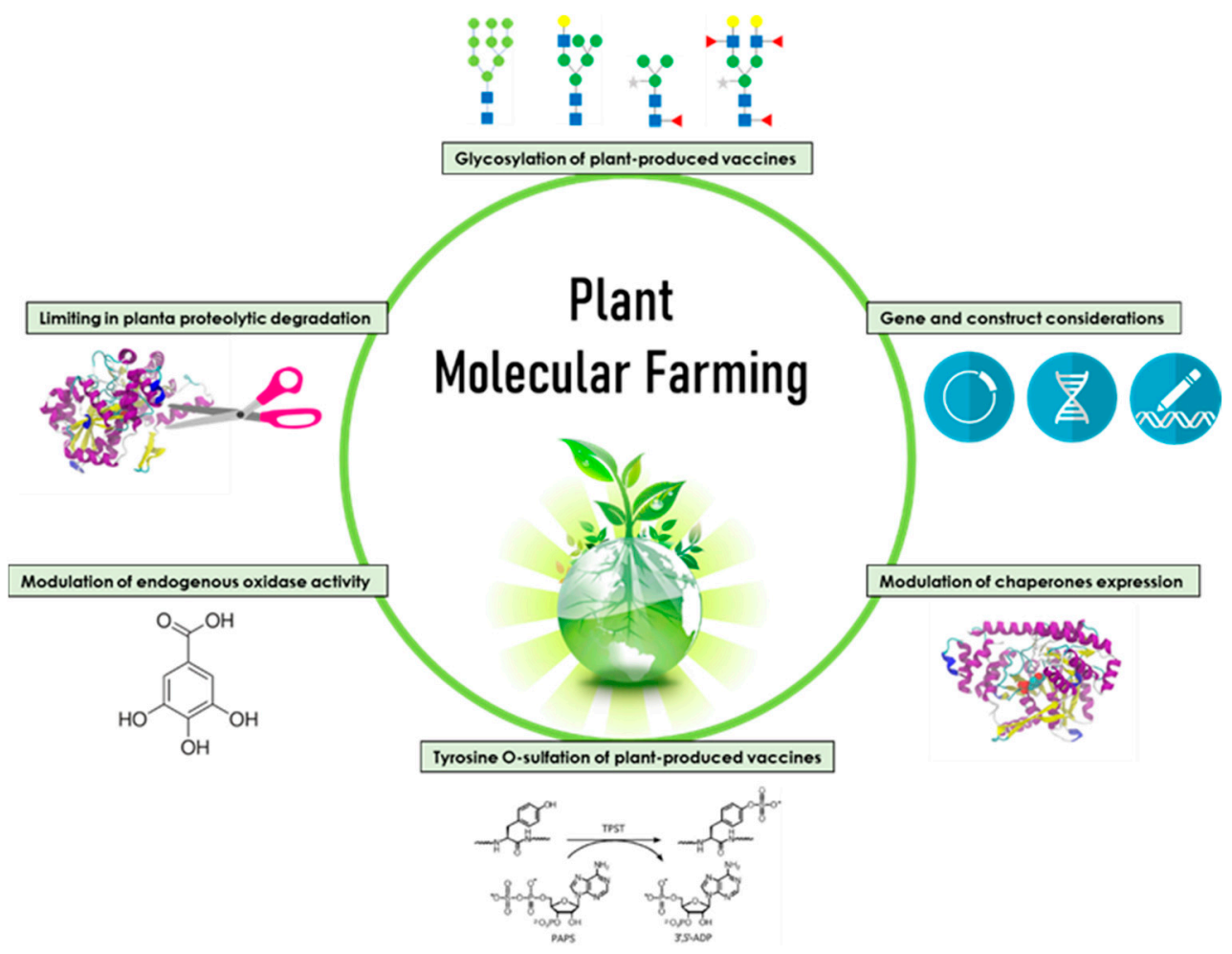

Figure 1. Engineering approaches in plant molecular farming.

\section{Improving the Yields of Recombinant Protein Vaccines}

\subsection{Gene and Construct Considerations}

One of the desired outcomes in molecular farming is to achieve a high-expression yield of recombinant protein. To achieve high-expression yields of recombinant proteins, expression constructs must be optimized at all stages, from transcript to protein stability. 
Recently, it has been suggested that guanine-cytosine (GC) content of the gene of interest does not affect recombinant protein accumulation alone. Another important driver is codon-anticodon kinetics, which may be a major driver for translation efficacy [19]. Codon bias can result in a gene from one species being poorly expressed in another host organism as a result of the presence of unfavourable codons [20-24]. Correlations between the use of host-specific codon usage and the accumulation of correctly folded, active-recombinant protein should be identified. The yield of recombinant protein can therefore be improved through codon harmonisation, which involves replacing messenger ribonucleic acid (mRNA) codons with those that are preferred by the host [25].

Plant expression vectors are typically chimeric structures that have been constructed from repurposed plant viruses, such as tobacco mosaic virus (TMV), cowpea mosaic virus (CPMV), alfalfa mosaic virus, and potato virus X (PVX) [26]. The latest virus-based vectors are the deconstructed vectors that have non-essential genes of the virus replaced with the coding sequences of the genes of interest or those that drive high levels of translation. Viral vectors are used because of their ability to replicate at high quantities. The most well-known transient expression system, the MagnICON system, relies on constructs with a TMV and a PVX backbone [27]. A popular alternative is the pEAQ-HT expression system, which is based on the CPMV and a variant that improved plant transient expression though the rational design of synthetic $5^{\prime}$ and $3^{\prime}$ untranslated regions, giving rise to a pHREAC expression system [28-30]. Cloned recombinant genes within these constructs are bordered by various regulatory elements. Two elements important for high levels of transcription are the promoter and the polyadenylation site, which are often derived from the $19 \mathrm{~S}$ and $35 \mathrm{~S}$ transcripts of the cauliflower mosaic virus (CaMV) [31,32]. The CaMV $35 \mathrm{~S}$ promoter has been the most popular choice for dicotyledonous plants (dicots), which are a strong constitutive promoter of the derived RNA transcripts. The arising RNA transcripts will be capped at its $5^{\prime}$ end by the cellular machinery, which is essential for translation in synergy with the poly (A) tail. The activity of the CaMV 35 S promoter can be enhanced by duplicating the enhancer region [33]. However, this promoter produces lower activity in monocotyledonous plants (monocots), for which a preferred alternative is the maize ubiquitin-1 promoter [34]. The most widely used polyadenylation site is that of the CaMV $35 \mathrm{~S}$ transcript, the Agrobacterium tumefaciens nos gene, and the pea ssu gene. Sequencedependent RNA degradation or silencing can reduce the yield of recombinant protein [35]. This can be prevented through the coexpression of the recombinant protein along with a viral silencing suppressor, several of which have been demonstrated transiently in $N$. benthamiana [36]. The p19 suppressor from tomato bushy stunt virus (TBSV) is perhaps the most well studied and functions by binding siRNA and prevents RISC assembly, thereby increasing recombinant protein yields [37].

\subsection{Modulation of Chaperone Expression}

Chaperones mediate the folding of proteins within the endoplasmic reticulum (ER). These chaperones provide stringent quality control and ensure that misfolded protein is targeted for endoplasmic reticulum-associated degradation (ERAD) [38]. Recombinant protein expression stresses the machinery, and by doing so, induces the unfolded protein response (UPR), which results in an increase in chaperone expression. The modulations of selected chaperones can therefore be used as a strategy to improve recombinant protein production. However, the alteration in the expression of these chaperones may also have an influence of the phenotype of the plant and the endogenous protein levels [39]. A slight increase above normal expression levels of binding protein 1 (BiP1) in transgenic rice increased the recombinant protein yield in rice seeds [39]. Subtle modulation of the ER-associated folding pathway was shown to increase recombinant protein yields; however, an alternative is the coexpression of the protein with a chaperone from another host [25]. Increases in yields in N. benthamiana were observed for several human viral glycoproteins destined for use as vaccine antigens in the presence of human calreticulin [25]. 
The coexpression of human calreticulin with HIV gp140 expression also resulted in an increase in accumulated yield of recombinant protein [40].

\subsection{Modulation of Endogenous Oxidase Activity}

The extraction of recombinantly produced protein in plants requires homogenisation of green leaf material; this process also results in the release of phenolic compounds. Polyphenol oxidases (PPOs) catalyse the formation of covalent complexes between the recombinant protein and the phenol compounds. This can result in the aggregation and precipitation of recombinant protein, significantly reducing yield and quality [41]. Reductions in phenolic oxidation can be achieved through the addition of antioxidant in the extraction buffer; however, this in turn can potentially increase the complexity of the extraction and the overall cost of the production process, affecting its techno-economic viability [42]. The adoption of ribonucleic acid interference (RNAi) targeting PPO has been shown to reduce the browning process of potato tubers and apples [43]. The clustered regularly interspaced short palindromic repeats (CRISPR)-associated, nuclease (CRISPR/Cas)-mediated knock out of a single member of the potato PO gene family also demonstrated a reduction in PPO activity by $69 \%$ without any phenotypic effects [44]. A similar approach can be adopted in Nicotiana spp.; however, since PPOs function in defence, elimination of PPO activity may interfere with normal plant growth and phenotypic properties.

\subsection{Limiting in Planta Proteolytic Degradation}

Proteases are triggered by developmental and environmental cues and function in a housekeeping role, activation of zymogens, removal of non-functional protein, and pathogen defence [45-48]. The targeting of recombinant proteins through the plant secretory pathway for post-translational modifications (PTMs), such as glycosylation and sulfation, makes them susceptible to proteases, which are auto-catalytically mature in low-pH environments [49,50]. The MEROPS database (28/04/2020) lists 515 known or putative peptidases and 98 non-peptidase homologues in $N$. benthamiana to date, which are possibly responsible for in planta degradation of some recombinantly produced proteins [51]. A major problem encountered with the plant-based production of protein in Nicotiana species is the in planta proteolytic degradation of some recombinantly produced proteins $[52,53]$. Proteolytic degradation is not only limited to in planta degradation during protein expression, ex planta degradation is also possible during extraction and downstream processing [53-57]. Proteolytic degradation may not only reduce the purity and yields of recombinantly produced protein but can also compromise the structural integrity of these proteins. Proteolytic degradation such as this can result in altered biological activity or no protein production at all, ultimately resulting in a bottleneck in the production of biopharmaceuticals [58-60]. Agrobacterium infiltration of plants such as N. benthamiana has been found to elicit an immune response, the hypersensitive response, which includes the induction of pathogenesis-related (PR) genes and the accumulation of extracellular PR proteins [61-63]. These responses not only reduce subsequent infection but may also hinder agrobacterium-mediated transgene delivery [64-67]. In conjunction with the hindrance of agrobacterium-mediated transgene delivery, the upregulation of these PR proteins causes the degradation of recombinantly produced protein and triggers the process of senescence, which results in the degradation of host cellular protein. Degradation of the chloroplastic protein occurs in the initial stages of senescence, resulting in reduced photosynthetic capacity of the leaf [68]. The downregulation of proteases has been shown to have beneficial effects on the accumulation of recombinantly produced protein [69]. Initial cleavage of recombinant protein is targeted to sterically exposed segments [70]. Reducing the in planta activities of these proteases could improve both the quality and yield of the produced recombinant protein [70].

Commonly employed strategies involve the use of ribonucleic acid interference (RNAi), or either the coexpression of companion protease inhibitors or proton channels, which have been previously used to create protease activity-depleted or inactive envi- 
ronments $[56,69,71,72]$. RNAi-targeted silencing of proteases has been demonstrated in whole-plant and cell suspension culture. Attempts were made to stably and transiently silence the CysP gene in whole tobacco plants [69]. Transient silencing of CysP6 was demonstrated to be the more successful strategy, which increased in planta accumulation of the recombinant protein of interest, interleukin (IL)-10, in comparison with transgenic silencing [69]. Protease silencing attempts in suspension cultures of cell lines producing the 2F5 antibody showed decreased protease degradation with increased accumulation of the antibody [56]. RNAi silencing of proteases has proven successful, alternatively, the coexpression of plant-derived protease inhibitors, such as cystatins, cysteine protease inhibitors are also possible [71,72]. Transgenic tobacco plants constitutively expressing the rice cysteine protease inhibitor oryzacytatin-I have significantly lower cysteine protease activity when compared with non-transgenic plants [71,73]. This lower cysteine protease activity has been shown to increase the production of recombinant protein [71]. Transiently expressing these protease inhibitors, such as tomato cystatin SICYS8 in the secretory pathways of $N$. benthamiana, has been shown to prevent degradation of recombinant protein [72]. Regulation of the $\mathrm{pH}$ in this pathway has been shown to reduce in planta proteolytic degradation of the recombinantly produced protein. A strategy for increasing the Golgi lumen $\mathrm{pH}$ through the coexpression of an influenza virus M2 proton channel successfully stabilised acid-labile recombinant proteins and peptides in leaf cells [74].

\section{Posttranslational Modifications of Plant-Produced Vaccines}

\subsection{Glycosylation of Plant-Produced Vaccines}

Many protein-based vaccines require glycosylation, yet the role of the glycosylating glycan may vary in functionality. Glycosylation in eukaryotic cells occurs in proteins that transit via the ER and Golgi secretory pathway [75]. Glycosylation occurs in three forms, namely: N-glycosylation on Asn residues, O-glycosylation on Ser/Thr or hydroxylated Lys and Pro residues, and C-glycosylation on Trp residues [75]. N-glycosylation is a major protein glycosylation type, influencing folding, trafficking, protein interactions, and efficacy of subunit vaccines and other biologics.

An example of this is the glycosylation of the Fc region of antibodies (Abs) and its significant impact on antibody effector functions, such as antibody-dependent, cellmediated cytotoxicity (ADCC) and antibody-dependent, cell-mediated virus inactivation (ADCVI) [76-78]. The initial stages of N-glycosylation and associated glycan processing occurs in the endoplasmic reticulum, a process that is conserved between mammals and plants. Further processing steps to form complex N-glycans occurs in the Golgi apparatus through a process that differs between mammals and plants. Plants lack the ability to produce highly complex N-glycans owing to fewer glycosyltransferases, which elongate the N-glycans. Plants also produce non-human glycans that contain $\beta 1,2$-xylose and/or $\alpha 1,3$-fucose residues [79], and these glycans have effects on the pharmacokinetics of a biopharmaceutical product, as well as immunogenicity in humans [80,81]. N. benthamiana has been glycoengineered by either the downregulation or elimination of xylosyl- and fucosyltransferase with RNAi and CRISPR/Cas9, respectively [82]. Production in this engineered host resulted in the transient production of mAbs with a predominantly mammalian GnGn glycan structure [80,81]. The resulting glycoforms are more homogenous than FDA-approved mAbs produced in mammalian cell cultures [80,81].

Plants lack the ability to produce complex N-glycans; to augment this, the glycosyltransferases and the entire pathway for the synthesis, transport, and transfer of the glycosylating residues must be introduced into the plants. Plants also lack the ability to perform the $\beta 1$,4-linked galactose (galactosylated) modification and to cap with sialic acid (N-acetylneuraminic acid, sialylated) residues. The transient and stable introduction of pathways have been developed to enable the incorporation of human-type-N-glycans with sialic acid onto glycoproteins [83-85]. The coordinated expression of both mammalian sialic acid pathways and human polysialyltransferases results in the formation of 
polysialic acid-containing glycoproteins with similar characteristics to their mammalian cell culture-derived variants [86].

Despite the ability to introduce human-like glycosylation, the ability to fully glycosylate available glycosylation sites in recombinant proteins remains a challenge. Members of the CAP256-VRC26 lineage of HIV antibodies have been produced in N. benthamiana $(\triangle \mathrm{XTFT})$, achieving approximately $50 \%$ glycosylation on the plant-produced Fc regions consistent with reports of other plant-produced Abs [87,88]. Incomplete glycosylation of transiently plant-produced proteins has been reported frequently $[80,89,90]$; however, close to complete glycosylation was achieved with plant-produced VRC01 [91]. However, this is dependent on the expression host; the extent of sequon occupancy has been observed to differ between plant species. Plant oligosaccharyltransferase (OST) complexes are made of multiple subunits; however, the composition and function of each is poorly understood $[92,93]$. As such, the cause of differences is still unknown. However, differences can arise from the inability of plants' OST complex to recognise the N-glycosylation site, resulting in incomplete glycosylation of the plant-produced glycoproteins. A viable approach to increase the in planta $\mathrm{N}$-glycosylation efficiency is through the coexpression of OST subunits [87]. The transient expression of a single subunit of the Leishmania major (L. major) OST complex resulted in increased N-glycan occupancy in various immunoglobulin structures [87].

Unlike with $\mathrm{N}$-glycans, less research focus has been placed on O-glycans, the second major type of glycosylation that is catalysed within the secretory pathway [94]. O-glycans are significant as O-glycans present on viral envelope glycoprotein, which are potential vaccine candidates [95]. This modification is catalysed by $\mathrm{N}$-acetylgalactosaminyltransferases, which plants lack, along with the glycotransferases that are responsible for the elongation and branching of these O-glycans [96]. These mammalian-type O-glycans can be generated de novo [96].

\subsection{Tyrosine O-Sulfation of Plant-Produced Vaccines}

Tyrosine sulfation is essential for protein-protein interactions, especially for antibodies (Abs) that target the V1V2 region of human immunodeficiency virus (HIV), such as PG9 and the CAP256-VRC26 lineage $[90,97,98]$. Antibodies play a pivotal role in possible vaccination strategies for pre-exposure prophylaxis against HIV. Functionality of V1V2 targeting $\mathrm{mAbs}$ requires an O-sulfated tyrosine in the CDR H3 loop of the antigen-binding domain to facilitate tight binding of the gp120 envelope glycoprotein in a manner that mimics the HIV-1 gp120 affinity for the sulfated CCR5 [99]. Tyrosine sulfation is catalysed by a tyrosylprotein sulfotransferase (TPST) that is localised to the subcellular trans-Golgi network, thereby limiting sulfation to proteins that transit through the secretory pathway (ER and Golgi). In plants, a putative TPST gene was identified by Komori and co-workers in Arabidopsis [100,101]. N. benthamiana is commonly used for Ab production; however, attempts to produce PG9 in planta resulted in inactive Ab due to the lack of tyrosine O-sulfation. This suggests that, unlike Arabidopsis, N. benthamiana lacks the necessary machinery to carry out tyrosine sulfation [102]. Previous attempts to find a TPST candidate in the N. benthamiana draft genome were unsuccessful $[90,103]$. Despite this, the expression of active V1V2 targeting antibodies, PG9, CAP256-VRC26.08, and CAP256-VRC26.09 in $N$. benthamiana was demonstrated. This was achieved through the transient coexpression of the mAbs with human TPST1 (hTPST1) engineered for post-Golgi targeting [88,90]. The coexpression of hTPST1 with CAP256-VRC26 antibodies produced both mono- and di-sulfated CAP256-VRC26 species and restored neutralising potency against a broad panel of HIV-1 strains [88].

\section{Conclusions and Future Impact of Engineering Strategies in Plant Molecular Farming}

During the last thirty years, great progress has been made in demonstrating the utility of plant production systems for producing protein-based vaccines. The utility of the plant production system was demonstrated during the coronavirus disease 2019 (COVID-19) 
pandemic, with vaccine candidates currently in various clinical trial phases. Two examples are the Medicago and GlaxoSmithKline coronavirus-like particle (CoVLP) (NCT04636697, Phase II/III) and the capsid virus-like particle (cVLP) from Kentucky Bioprocessing, Inc. (NCT04473690, Phase I/II). Various engineering approaches have been demonstrated to tailor-make authentic protein-based vaccines at sufficient yields. These approaches allow the engineering of the plant expression systems, enabling the production of increasingly complex protein molecules with correct PTMs. Obtaining correctly folded protein is of critical importance to protein function. The further exploration of recombinant protein and chaperone coexpression combinations is of great interest in optimising the host secretory pathway for increased recombinant protein yield. In so doing, the exploration of new frontiers of PTMs, such as the incorporation of O-glycan structures to viral envelope glycoproteins, is of potential medical interest.

In planta and ex planta oxidation and proteolytic degradation remain as much a hurdle to produce structurally correct and functional plant-produced intravenous vaccines as they do for edible vaccines. These deleterious processes are not limited to the extraction process during the downstream processing of plant-produced intravenous vaccines. An area of growing interest is the modulation of deleterious host cell proteins, which are not essential to plant growth and production of functional recombinant protein, in an attempt to both simplify the downstream processing and increase synthesis capacity. The development and optimisation of CRISPR/Cas9-based genome editing allows for precise modification of the plant genome, creating the basic chassis for tailoring the production of any protein-based vaccine or pharmaceutical. Improved capacity can be achieved through the diversion of plant cell molecular machinery from host cell protein to the production of the target recombinant protein. Reducing the abundance of host cell protein, such as ribulose-1,5-bisphosphate carboxylase/oxygenase (RuBisCO), which can account for $40 \%$ of the total soluble protein (TSP) in leaf cells, can facilitate the simpler downstream processing of the recombinant protein. In generating tailor-made plants to produce certain protein-based pharmaceuticals, it is important to consider introducing whole pathways to incorporate human-like PTMs specific to the recombinant protein of interest. These engineering prospects will promote future advances in the plant molecular farming field. Though the optimal utility of the plant system is yet to be realised, we hope that these developments will bring about more traction in attracting the adoption of plant molecular farming field for global health.

Author Contributions: A.A.S. formulated and wrote the manuscript with input from P.P. and T.L.T.; P.P. and T.L.T. critically reviewed, edited, and revised the paper. All authors have read and agreed to the published version of the manuscript.

Funding: This research did not receive any specific grant from funding agencies in the public, commercial, or not-for-profit sectors.

Institutional Review Board Statement: Not applicable.

Conflicts of Interest: The authors declare no conflict of interest.

\section{Abbreviations}

mRNA: TMV: PVX, CPMV, CaMV, TBSV, ER, ERAD, UPR, BiP1, PPOs, CRISPR/Cas9, PR, ADCC, ADCVI, OST, Abs, TPST, hTPST, TSP.

\section{References}

1. Pollard, A.J.; Bijker, E.M. A guide to vaccinology: From basic principles to new developments. Nat. Rev. Immunol. 2021, 21, 83-100. [CrossRef] [PubMed]

2. Swartz, J.R. Advances in Escherichia coli production of therapeutic proteins. Curr. Opin. Biotechnol. 2001, 12, 195-201. [CrossRef]

3. Chu, L.; Robinson, D.K. Industrial choices for protein production by large-scale cell culture. Curr. Opin. Biotechnol. 2001, 12, 180-187. [CrossRef]

4. Houdebine, L.M. Transgenic animal bioreactors. Transgenic Res. 2000, 9, 305-320. [CrossRef] 
5. Barta, A.; Sommergruber, K.; Thompson, D.; Hartmuth, K.; Matzke, M.A.; Matzke, A.J. The expression of a nopaline synthasehuman growth hormone chimaeric gene in transformed tobacco and sunflower callus tissue. Plant Mol. Biol. 1986, 6, 347-357. [CrossRef]

6. Hiatt, A.; Caffferkey, R.; Bowdish, K. Production of antibodies in transgenic plants. Nature 1989, 342, 76-78. [CrossRef]

7. De Martinis, D.; Rybicki, E.P.; Fujiyama, K.; Franconi, R.; Benvenuto, E. Plant molecular farming: Fast, scalable, cheap, sustainable. Front. Plant Sci. 2016, 7, 1148. [CrossRef] [PubMed]

8. Nandi, S.; Kwong, A.T.; Holtz, B.R.; Erwin, R.L.; Marcel, S.; McDonald, K.A. Techno-Economic Analysis of a Transient Plant-Based Platform for Monoclonal antibodyProduction. $m A$ ss 2016, 8, 1456-1466. [CrossRef]

9. Pillet, S.; Aubin, É.; Trépanier, S.; Bussière, D.; Dargis, M.; Poulin, J.-F.; Yassine-Diab, B.; Ward, B.J.; Landry, N. A plant-derived quadrivalent virus like particle influenza vaccine induces cross-reactive antibody and $\mathrm{T}$ cell response in healthy adults. Clin. Immunol. 2016, 168, 72-87. [CrossRef]

10. De Muynck, B.; Navarre, C.; Boutry, M. Production of antibodies in plants: Status after twenty years. Plant Biotechnol. J. 2010, 8, 529-563. [CrossRef]

11. Fischer, R.; Emans, N. Molecular farming of pharmaceutical proteins. Transgenic Res. 2000, 9, 279-299. [CrossRef] [PubMed]

12. Giddings, G. Transgenic plants as protein factories. Curr. Opin. Biotechnol. 2001, 12, 450-454. [CrossRef]

13. Spiegel, H.; Stöger, E.; Twyman, R.M.; Buyel, J.F. Current status and perspectives of the molecular farming landscape. In Molecular Pharming: Applications, Challenges and Emerging Areas; John Wiley \& Sons, Inc.: Hoboken, NJ, USA, 2018; pp. 3-23.

14. Nölke, G.; Fischer, R.; Schillberg, S. Production of therapeutic antibodies in plants. Expert Opin. Biol. Ther. 2003, 3, 1153-1162. [CrossRef]

15. Twyman, R.M.; Schillberg, S.; Fischer, R. Transgenic plants in the biopharmaceutical market. Expert Opin. Emerg. Drugs 2005, 10, 185-218. [CrossRef]

16. Schillberg, S.; Raven, N.; Fischer, R.; Twyman, R.M.; Schiermeyer, A. Molecular farming of pharmaceutical proteins using plant suspension cell and tissue cultures. Curr. Pharm. Des. 2013, 19, 5531-5542. [CrossRef] [PubMed]

17. Tsekoa, T.L.; Singh, A.A.; Buthelezi, S.G. Molecular farming for therapies and vaccines in Africa. Curr. Opin. Biotechnol. 2020, 61, 89-95. [CrossRef]

18. Schillberg, S.; Finnern, R. Plant molecular farming for the production of valuable proteins-Critical evaluation of achievements and future challenges. J. Plant Physiol. 2021, 258, 153359. [CrossRef] [PubMed]

19. Sahoo, S.; Das, S.S.; Rakshit, R. Codon usage pattern and predicted gene expression in Arabidopsis thaliana. Gene X 2019, 2, 100012. [CrossRef] [PubMed]

20. Gouy, M.; Gautier, C. Codon usage in bacteria: Correlation with gene expressivity. Nucleic Acids Res. 1982, 10, 7055-7074. [CrossRef]

21. Webster, G.R.; Teh, A.Y.H.; Ma, J.K.C. Synthetic gene design-The rationale for codon optimization and implications for molecular pharming in plants. Biotechnol. Bioeng. 2017, 114, 492-502. [CrossRef]

22. Mahalik, S.; Sharma, A.K.; Mukherjee, K.J. Genome engineering for improved recombinant protein expression in Escherichia coli. Microb. Cell Factories 2014, 13, 177. [CrossRef] [PubMed]

23. Liu, Y.; Beyer, A.; Aebersold, R. On the dependency of cellular protein levels on mRNA abundance. Cell 2016, 165, 535-550. [CrossRef]

24. Gustafsson, C.; Govindarajan, S.; Minshull, J. Codon bias and heterologous protein expression. Trends Biotechnol. 2004, 22, 346-353. [CrossRef]

25. Buyel, J.; Stöger, E.; Bortesi, L. Targeted genome editing of plants and plant cells for biomanufacturing. Transgenic Res. 2021, 30, 101-426. [CrossRef]

26. Salazar-González, J.A.; Bañuelos-Hernández, B.; Rosales-Mendoza, S. Current status of viral expression systems in plants and perspectives for oral vaccines development. Plant Mol. Biol. 2015, 87, 203-217. [CrossRef]

27. Giritch, A.; Marillonnet, S.; Engler, C.; van Eldik, G.; Botterman, J.; Klimyuk, V.; Gleba, Y. Rapid high-yield expression of full-size IgG antibodies in plants coinfected with noncompeting viral vectors. Proc. Natl. Acad. Sci. USA 2006, 103, 14701-14706. [CrossRef]

28. Peyret, H.; Brown, J.K.; Lomonossoff, G.P. Improving plant transient expression through the rational design of synthetic $5^{\prime}$ and $3^{\prime}$ untranslated regions. Plant Methods 2019, 15, 108. [CrossRef] [PubMed]

29. Sainsbury, F.; Thuenemann, E.C.; Lomonossoff, G.P. pEAQ: Versatile expression vectors for easy and quick transient expression of heterologous proteins in plants. Plant Biotechnol. J. 2009, 7, 682-693. [CrossRef]

30. Peyret, H.; Lomonossoff, G.P. The pEAQ vector series: The easy and quick way to produce recombinant proteins in plants. Plant Mol. Biol. 2013, 83, 51-58. [CrossRef] [PubMed]

31. Odell, J.T.; Nagy, F.; Chua, N.-H. Identification of DNA sequences required for activity of the cauliflower mosaic virus 35S promoter. Nature 1985, 313, 810-812. [CrossRef]

32. Lawton, M.A.; Tierney, M.A.; Nakamura, I.; Anderson, E.; Komeda, Y.; Dubé, P.; Hoffman, N.; Fraley, R.T.; Beachy, R.N. Expression of a soybean $\beta$-conclycinin gene under the control of the cauliflower mosaic virus $35 \mathrm{~S}$ and 195 promoters in transformed petunia tissues. Plant Mol. Biol. 1987, 9, 315-324. [CrossRef]

33. Kay, R.; Chan, A.; Daly, M.; McPherson, J. Duplication of CaMV 35S promoter sequences creates a strong enhancer for plant genes. Science 1987, 236, 1299-1302. [CrossRef] [PubMed]

34. Christensen, A.H.; Quail, P.H. Ubiquitin promoter-based vectors for high-level expression of selectable and/or screenable marker genes in monocotyledonous plants. Transgenic Res. 1996, 5, 213-218. [CrossRef] [PubMed]

35. Brodersen, P.; Voinnet, O. The diversity of RNA silencing pathways in plants. TRENDS Genet. 2006, 22, 268-280. [CrossRef] [PubMed] 
36. Arzola, L.; Chen, J.; Rattanaporn, K.; Maclean, J.M.; McDonald, K.A. Transient co-expression of post-transcriptional gene silencing suppressors for increased in planta expression of a recombinant anthrax receptor fusion protein. Int. J. Mol. Sci. 2011, 12, 4975-4990. [CrossRef] [PubMed]

37. Garabagi, F.; Gilbert, E.; Loos, A.; McLean, M.D.; Hall, J.C. Utility of the P 19 suppressor of gene-silencing protein for production of therapeutic antibodies in N icotiana expression hosts. Plant Biotechnol. J. 2012, 10, 1118-1128. [CrossRef]

38. Strasser, R. Protein quality control in the endoplasmic reticulum of plants. Annu. Rev. Plant Biol. 2018, 69, 147-172. [CrossRef]

39. Wakasa, Y.; Yasuda, H.; Oono, Y.; Kawakatsu, T.; Hirose, S.; Takahashi, H.; Hayashi, S.; Yang, L.; Takaiwa, F. Expression of ER quality control-related genes in response to changes in BiP1 levels in developing rice endosperm. Plant J. 2011, 65, 675-689. [CrossRef]

40. Margolin, E.; Oh, Y.J.; Verbeek, M.; Naude, J.; Ponndorf, D.; Meshcheriakova, Y.A.; Peyret, H.; van Diepen, M.T.; Chapman, R.; Meyers, A.E. Co-expression of human calreticulin significantly improves the production of HIV gp140 and other viral glycoproteins in plants. Plant Biotechnol. J. 2020, 18, 2109-2117. [CrossRef]

41. Twyman, R.M.; Stoger, E.; Schillberg, S.; Christou, P.; Fischer, R. Molecular farming in plants: Host systems and expression technology. Trends Biotechnol. 2003, 21, 570-578. [CrossRef]

42. Buyel, J.; Twyman, R.; Fischer, R. Extraction and downstream processing of plant-derived recombinant proteins. Biotechnol. Adv. 2015, 33, 902-913. [CrossRef]

43. Nadakuduti, S.S.; Buell, C.R.; Voytas, D.F.; Starker, C.G.; Douches, D.S. Genome editing for crop improvement-Applications in clonally propagated polyploids with a focus on potato (Solanum tuberosum L.). Front. Plant Sci. 2018, 9, 1607. [CrossRef] [PubMed]

44. González, M.N.; Massa, G.A.; Andersson, M.; Turesson, H.; Olsson, N.; Fält, A.-S.; Storani, L.; Décima Oneto, C.A.; Hofvander, P.; Feingold, S.E. Reduced enzymatic browning in potato tubers by specific editing of a polyphenol oxidase gene via ribonucleoprotein complexes delivery of the CRISPR/Cas9 system. Front. Plant Sci. 2020, 10, 1649. [CrossRef]

45. van der Hoorn, R.A.L.; Jones, J.D.G. The plant proteolytic machinery and its role in defence. Curr. Opin. Plant Biol. 2004, 7, 400-407. [CrossRef] [PubMed]

46. van der Hoorn, R.A.L. Plant Proteases: From Phenotypes to Molecular Mechanisms. Annu. Rev. Plant Biol. 2008, 59, 191-223. [CrossRef]

47. Grosse-Holz, F.; Kelly, S.; Blaskowski, S.; Kaschani, F.; Kaiser, M.; van der Hoorn, R.A. The transcriptome, extracellular proteome and active secretome of agroinfiltrated Nicotiana benthamiana uncover a large, diverse protease repertoire. Plant Biotechnol. J. 2018, 16, 1068-1084. [CrossRef]

48. Schaller, A. A cut above the rest: The regulatory function of plant proteases. Planta 2004, 220, 183-197. [CrossRef]

49. Zauner, F.B.; Dall, E.; Regl, C.; Grassi, L.; Huber, C.G.; Cabrele, C.; Brandstetter, H. Crystal structure of plant legumain reveals a unique two-chain state with pH-dependent activity regulation. Plant Cell 2018, 30, 686-699. [CrossRef] [PubMed]

50. Gu, C.; Shabab, M.; Strasser, R.; Wolters, P.J.; Shindo, T.; Niemer, M.; Kaschani, F.; Mach, L.; van der Hoorn, R. Post-translational regulation and trafficking of the granulin-containing protease RD21 of Arabidopsis thaliana. PLoS ONE 2012, 7, e32422. [CrossRef]

51. Rawlings, N.D.; Barrett, A.J.; Thomas, P.D.; Huang, X.; Bateman, A.; Finn, R.D. The MEROPS database of proteolytic enzymes, their substrates and inhibitors in 2017 and a comparison with peptidases in the PANTHER database. Nucleic Acids Res. 2018, 46, D624-D632. [CrossRef]

52. Doran, P.M. Foreign protein degradation and instability in plants and plant tissue cultures. Trends Biotechnol. 2006, 24, 426-432. [CrossRef]

53. Benchabane, M.; Goulet, C.; Rivard, D.; Faye, L.; Gomord, V.; Michaud, D. Preventing unintended proteolysis in plant protein biofactories. Plant Biotechnol. J. 2008, 6, 633-648. [CrossRef]

54. Rivard, D.; Anguenot, R.; Brunelle, F.; Le, V.Q.; Vézina, L.P.; Trépanier, S.; Michaud, D. An in-built proteinase inhibitor system for the protection of recombinant proteins recovered from transgenic plants. Plant Biotechnol. J. 2006, 4, 359-368. [CrossRef] [PubMed]

55. Hehle, V.K.; Lombardi, R.; Dolleweerd, C.J.; Paul, M.J.; Di Micco, P.; Morea, V.; Benvenuto, E.; Donini, M.; Ma, J.K.C. Sitespecific proteolytic degradation of IgG monoclonal antibodies expressed in tobacco plants. Plant Biotechnol. J. 2015, 13, 235-245. [CrossRef] [PubMed]

56. Mandal, M.K.; Fischer, R.; Schillberg, S.; Schiermeyer, A. Inhibition of protease activity by antisense RNA improves recombinant protein production in Nicotiana tabacum cv. Bright Yellow 2 (BY-2) suspension cells. Biotechnol. J. 2014, 9, 1065-1073. [CrossRef]

57. Niemer, M.; Mehofer, U.; Torres Acosta, J.A.; Verdianz, M.; Henkel, T.; Loos, A.; Strasser, R.; Maresch, D.; Rademacher, T.; Steinkellner, H. The human anti-HIV antibodies 2F5, 2G12, and PG9 differ in their susceptibility to proteolytic degradation: Down-regulation of endogenous serine and cysteine proteinase activities could improve antibody production in plant-based expression platforms. Biotechnol. J. 2014, 9, 493-500. [CrossRef]

58. Mandal, M.K.; Ahvari, H.; Schillberg, S.; Schiermeyer, A. Tackling Unwanted Proteolysis in Plant Production Hosts Used for Molecular Farming. Front. Plant Sci. 2016, 7, 267. [CrossRef]

59. Castilho, A.; Windwarder, M.; Gattinger, P.; Mach, L.; Strasser, R.; Altmann, F.; Steinkellner, H. Proteolytic and N-Glycan Processing of Human $\alpha 1$-Antitrypsin Expressed in Nicotiana benthamiana. Plant Physiol. 2014, 166, 1839-1851. [CrossRef] [PubMed]

60. Faye, L.; Boulaflous, A.; Benchabane, M.; Gomord, V.; Michaud, D. Protein modifications in the plant secretory pathway: Current status and practical implications in molecular pharming. Vaccine 2005, 23, 1770-1778. [CrossRef]

61. Goulet, C.; Goulet, C.; Goulet, M.-C.; Michaud, D. 2-DE proteome maps for the leaf apoplast of Nicotiana benthamiana. Proteomics 2010, 10, 2536-2544. [CrossRef] 
62. Zhou, Y.; Cox, A.M.; Kearney, C.M. Pathogenesis-related proteins induced by agroinoculation-associated cell wall weakening can be obviated by spray-on inoculation or mannitol ex vivo culture. Plant Biotechnol. Rep. 2017, 11, 161-169. [CrossRef]

63. Pitzschke, A. Agrobacterium infection and plant defense-transformation success hangs by a thread. Front. Plant Sci. 2015, 4, 519. [CrossRef]

64. Li, W.; Cao, J.Y.; Xu, Y.P.; Cai, X.Z. Artificial Agrobacterium tumefaciens strains exhibit diverse mechanisms to repress Xanthomonas oryzae pv. oryzae-induced hypersensitive response and non-host resistance in Nicotiana benthamiana. Mol. Plant Pathol. 2017, 18, 489-502. [CrossRef]

65. Rico, A.; Bennett, M.H.; Forcat, S.; Huang, W.E.; Preston, G.M. Agroinfiltration reduces ABA levels and suppresses Pseudomonas syringae-elicited salicylic acid production in Nicotiana tabacum. PLoS ONE 2010, 5, e8977. [CrossRef]

66. Robinette, D.; Matthysse, A. Inhibition by Agrobacterium tumefaciens and Pseudomonas savastanoi of development of the hypersensitive response elicited by Pseudomonas syringae pv. phaseolicola. J. Bacteriol. 1990, 172, 5742-5749. [CrossRef] [PubMed]

67. Sheikh, A.H.; Raghuram, B.; Eschen-Lippold, L.; Scheel, D.; Lee, J.; Sinha, A.K. Agroinfiltration by Cytokinin-Producing Agrobacterium sp. Strain GV3101 Primes Defense Responses in Nicotiana tabacum. Mol. Plant-Microbe Interact. 2014, 27, 1175-1185. [CrossRef] [PubMed]

68. Hörtensteiner, S.; Feller, U. Nitrogen metabolism and remobilization during senescence. J. Exp. Bot. 2002, 53, 927-937. [CrossRef]

69. Duwadi, K.; Chen, L.; Menassa, R.; Dhaubhadel, S. Identification, characterization and down-Regulation of cysteine Protease genes in tobacco for use in recombinant protein production. PLOS ONE 2015, 10, e0130556. [CrossRef]

70. Paireder, M.; Tholen, S.; Porodko, A.; Biniossek, M.L.; Mayer, B.; Novinec, M.; Schilling, O.; Mach, L. The papain-like cysteine proteinases $\mathrm{NbCysP6}$ and $\mathrm{NbCysP7}$ are highly processive enzymes with substrate specificities complementary to Nicotiana benthamiana cathepsin B. Biochim. Biophys. Acta (BBA)-Proteins Proteom. 2017, 1865, 444-452. [CrossRef]

71. Pillay, P.; Kibido, T.; Plessis, M.; Vyver, C.; Beyene, G.; Vorster, B.J.; Kunert, K.J.; Schlüter, U. Use of Transgenic Oryzacystatin-IExpressing Plants Enhances Recombinant Protein Production. Appl. Biochem Biotechnol. 2012, 168, 1608-1620. [CrossRef]

72. Girard, C.; Rivard, D.; Kiggundu, A.; Kunert, K.; Gleddie, S.C.; Cloutier, C.; Michaud, D. A multicomponent, elicitor-inducible cystatin complex in tomato, Solanum lycopersicum. New Phytol. 2007, 173, 841-851. [CrossRef] [PubMed]

73. Van der Vyver, C.; Schneidereit, J.; Driscoll, S.; Turner, J.; Kunert, K.; Foyer, C.H. Oryzacystatin I expression in transformed tobacco produces a conditional growth phenotype and enhances chilling tolerance. Plant Biotechnol. J. 2003, 1, 101-112. [CrossRef]

74. Jutras, P.V.; D’Aoust, M.A.; Couture, M.M.J.; Vézina, L.P.; Goulet, M.C.; Michaud, D.; Sainsbury, F. Modulating secretory pathway $\mathrm{pH}$ by proton channel co-expression can increase recombinant protein stability in plants. Biotechnol. J. 2015, 10, 1478-1486. [CrossRef] [PubMed]

75. Lin, H.; Du, J.; Jiang, H. Post-Translation Modifications to Regulate Protein Function; John Wiley \& Sons, Inc.: Hoboken, NJ, USA, 2008; pp. 1-31.

76. Lewis, G.K. Qualitative and quantitative variables that affect the potency of Fc-mediated effector function in vitro and in vivo: Considerations for passive immunization using non-neutralizing antibodies. Curr. HIV Res. 2013, 11, 354-364. [CrossRef]

77. Baum, L.L.; Cassutt, K.J.; Knigge, K.; Khattri, R.; Margolick, J.; Rinaldo, C.; Kleeberger, C.A.; Nishanian, P.; Henrard, D.R.; Phair, J. HIV-1 gp120-specific antibody-dependent cell-mediated cytotoxicity correlates with rate of disease progression. J. Immunol. 1996, 157, 2168-2173. [PubMed]

78. Shields, R.L.; Lai, J.; Keck, R.; O'Connell, L.Y.; Hong, K.; Meng, Y.G.; Weikert, S.H.; Presta, L.G. Lack of fucose on human IgG1 $\mathrm{N}$-linked oligosaccharide improves binding to human Fc $\gamma$ RIII and antibody-dependent cellular toxicity. J. Biol. Chem. 2002, 277, 26733-26740. [CrossRef]

79. Whaley, K.J.; Hiatt, A.; Zeitlin, L. Emerging antibody products and Nicotiana manufacturing. Hum. Vaccines 2011, 7, 349-356. [CrossRef] [PubMed]

80. Strasser, R.; Stadlmann, J.; Schähs, M.; Stiegler, G.; Quendler, H.; Mach, L.; Glössl, J.; Weterings, K.; Pabst, M.; Steinkellner, $\mathrm{H}$. Generation of glyco-engineered Nicotiana benthamiana for the production of monoclonal antibodies with a homogeneous human-like N-glycan structure. Plant Biotechnol. J. 2008, 6, 392-402. [CrossRef]

81. Strasser, R.; Castilho, A.; Stadlmann, J.; Kunert, R.; Quendler, H.; Gattinger, P.; Jez, J.; Rademacher, T.; Altmann, F.; Mach, L. Improved virus neutralization by plant-produced anti-HIV antibodies with a homogeneous $\beta 1$, 4-galactosylated N-glycan profile. J. Biol. Chem. 2009, 284, 20479-20485. [CrossRef]

82. Jansing, J.; Sack, M.; Augustine, S.M.; Fischer, R.; Bortesi, L. CRISPR/Cas9-mediated knockout of six glycosyltransferase genes in Nicotiana benthamiana for the production of recombinant proteins lacking $\beta-1,2$-xylose and core $\alpha-1$, 3-fucose. Plant Biotechnol. J. 2019, 17, 350-361. [CrossRef]

83. Montero-Morales, L.; Steinkellner, H. Advanced Plant-Based Glycan Engineering. Front. Bioeng. Biotechnol. 2018. [CrossRef]

84. Montero-Morales, L.; Maresch, D.; Crescioli, S.; Castilho, A.; Ilieva, K.M.; Mele, S.; Karagiannis, S.N.; Altmann, F.; Steinkellner, H. In planta glycan engineering and functional activities of IgE antibodies. Front. Bioeng. Biotechnol. 2019, 7, 242. [CrossRef] [PubMed]

85. Göritzer, K.; Turupcu, A.; Maresch, D.; Novak, J.; Altmann, F.; Oostenbrink, C.; Obinger, C.; Strasser, R. Distinct Fc $\alpha$ receptor $\mathrm{N}$-glycans modulate the binding affinity to immunoglobulin A (IgA) antibodies. J. Biol. Chem. 2019, 294, 13995-14008. [CrossRef]

86. Kallolimath, S.; Castilho, A.; Strasser, R.; Grünwald-Gruber, C.; Altmann, F.; Strubl, S.; Galuska, C.E.; Zlatina, K.; Galuska, S.P.; Werner, S. Engineering of complex protein sialylation in plants. Proc. Natl. Acad. Sci. USA 2016, 113, 9498-9503. [CrossRef] 
87. Castilho, A.; Beihammer, G.; Pfeiffer, C.; Göritzer, K.; Montero-Morales, L.; Vavra, U.; Maresch, D.; Grünwald-Gruber, C.; Altmann, F.; Steinkellner, H. An oligosaccharyltransferase from Leishmania major increases the N-glycan occupancy on recombinant glycoproteins produced in Nicotiana benthamiana. Plant Biotechnol. J. 2018, 16, 1700-1709. [CrossRef]

88. Singh, A.A.; Pooe, O.; Kwezi, L.; Lotter-Stark, T.; Stoychev, S.H.; Alexandra, K.; Gerber, I.; Bhiman, J.N.; Vorster, J.; Pauly, M. Plant-based production of highly potent anti-HiV antibodies with engineered posttranslational modifications. Sci. Rep. 2020, 10, 6201. [CrossRef] [PubMed]

89. Bendandi, M.; Marillonnet, S.; Kandzia, R.; Thieme, F.; Nickstadt, A.; Herz, S.; Fröde, R.; Inoges, S.; de Cerio, A.L.-D.; Soria, E. Rapid, high-yield production in plants of individualized idiotype vaccines for non-Hodgkin's lymphoma. Ann. Oncol. 2010, 21, 2420-2427. [CrossRef] [PubMed]

90. Loos, A.; Gach, J.S.; Hackl, T.; Maresch, D.; Henkel, T.; Porodko, A.; Bui-Minh, D.; Sommeregger, W.; Wozniak-Knopp, G.; Forthal, D.N. Glycan modulation and sulfoengineering of anti-HIV-1 monoclonal antibody PG9 in plants. Proc. Natl. Acad. Sci. USA 2015, 112, 12675-12680. [CrossRef]

91. Stelter, S.; Paul, M.; Teh, A.; Grandits, M.; Altmann, F.; Vanier, J.; Bardor, M.; Castilho, A.; Allen, R.; Ma, J. Engineering the interactions between a plant-produced HIV antibody and human Fc receptors. Plant Biotechnol. J. 2020, 18, 402-414. [CrossRef]

92. Strasser, R. Plant protein glycosylation. Glycobiology 2016, 26, 926-939. [CrossRef]

93. Jeong, I.S.; Lee, S.; Bonkhofer, F.; Tolley, J.; Fukudome, A.; Nagashima, Y.; May, K.; Rips, S.; Lee, S.Y.; Gallois, P. Purification and characterization of Arabidopsis thaliana oligosaccharyltransferase complexes from the native host: A protein super-expression system for structural studies. Plant J. 2018, 94, 131-145. [CrossRef]

94. Wohlschlager, T.; Scheffler, K.; Forstenlehner, I.C.; Skala, W.; Senn, S.; Damoc, E.; Holzmann, J.; Huber, C.G. Native mass spectrometry combined with enzymatic dissection unravels glycoform heterogeneity of biopharmaceuticals. Nat. Commun. 2018, 9, 1713. [CrossRef]

95. Bagdonaite, I.; Wandall, H.H. Global aspects of viral glycosylation. Glycobiology 2018, 28, 443-467. [CrossRef]

96. Castilho, A.; Steinkellner, H. Glyco-engineering in plants to produce human-like N-glycan structures. Biotechnol. J. 2012, 7, 1088-1098. [CrossRef] [PubMed]

97. Stone, M.J.; Chuang, S.; Hou, X.; Shoham, M.; Zhu, J.Z. Tyrosine sulfation: An increasingly recognised post-translational modification of secreted proteins. New Biotechnol. 2009, 25, 299-317. [CrossRef]

98. Doria-Rose, N.A.; Schramm, C.A.; Gorman, J.; Moore, P.L.; Bhiman, J.N.; DeKosky, B.J.; Ernandes, M.J.; Georgiev, I.S.; Kim, H.J.; Pancera, M. Developmental pathway for potent V1V2-directed HIV-neutralizing antibodies. Nature 2014, 509, 55-62. [CrossRef] [PubMed]

99. Choe, H.; Li, W.; Wright, P.L.; Vasilieva, N.; Venturi, M.; Huang, C.-C.; Grundner, C.; Dorfman, T.; Zwick, M.B.; Wang, L. Tyrosine sulfation of human antibodies contributes to recognition of the CCR5 binding region of HIV-1 gp120. Cell 2003, 114, 161-170. [CrossRef]

100. Komori, R.; Amano, Y.; Ogawa-Ohnishi, M.; Matsubayashi, Y. Identification of tyrosylprotein sulfotransferase in Arabidopsis. Proc. Natl. Acad. Sci. USA 2009, 106, 15067-15072. [CrossRef]

101. Moore, K.L. Protein tyrosine sulfation: A critical posttranslation modification in plants and animals. Proc. Natl. Acad. Sci. USA 2009, 106, 14741-14742. [CrossRef] [PubMed]

102. Rosenberg, Y.; Sack, M.; Montefiori, D.; Labranche, C.; Lewis, M.; Urban, L. Pharmacokinetics and Immunogenicity of Broadly Neutralizing HIV Monoclonal Antibodies in Macaques. PLoS ONE 2015, 10, e0120451. [CrossRef]

103. Bombarely, A.; Rosli, H.G.; Vrebalov, J.; Moffett, P.; Mueller, L.A.; Martin, G.B. A draft genome sequence of Nicotiana benthamiana to enhance molecular plant-microbe biology research. Mol. Plant Microbe Interact. 2012, 25, 1523-1530. [CrossRef] [PubMed] 